\title{
Chemoprotective effect of atorvastatin against benzo(a)pyrene-induced lung cancer via the inhibition of oxidative stress and inflammatory parameters
}

\author{
Xusheng Du ${ }^{1}$, Dongfan $\mathrm{Li}^{1}$, Guanjie Wang ${ }^{2}$, Yali Fan ${ }^{1}$, Namiao Li ${ }^{1,3}$, Lili Chai ${ }^{4}$, Guangshun $\mathrm{Li}^{5}$, \\ Jianying $\mathrm{Li}^{1}$
}

${ }^{1}$ Department of Respiratory, Affiliated Xi'an Central Hospital, The Medical School of Xi'an Jiaotong University, Xi'an, China; ${ }^{2}$ Department of Oncology, Affiliated Xi'an Central Hospital, The Medical School of Xi'an Jiaotong University, Xi'an, China; ${ }^{3}$ Medical College, Yan'an University, Yan'an, China; ${ }^{4}$ Department of Pathology, Affiliated Xi'an Central Hospital, The Medical School of Xi'an Jiaotong University, Xi'an, China; ${ }^{5}$ Department of Thoracic Surgery, Xi'an Central Hospital, Xi'an, China

Contributions: (I) Conception and design: J Li; (II) Administrative support: Y Fan; (III) Provision of study materials or patients: D Li, G Wang; (IV) Collection and assembly of data: X Du; (V) Data analysis and interpretation: J Li, L Chai; (VI) Manuscript writing: All authors; (VII) Final approval of manuscript: All authors.

Correspondence to: Jianying Li. Department of Respiratory, Affiliated Xi'an Central Hospital, The Medical School of Xi'an Jiaotong University, Xi'an 710003, China. Email: jianyinglihx@sina.com.

Background: Lung cancer affects approximately $9 \%$ of women and $17 \%$ of men worldwide, and has a mortality rate of $17 \%$. Previously published studies have suggested that oxidative stress expansion can lead to lung cancer. The aim of the current study was to analyze the possible inhibitory pathway of atorvastatin against lung cancer cells in an in vivo model.

Methods: The cytotoxic effects of atorvastatin on lung cancer cell lines H460 and A549 were analyzed, as well as cell cycle arrest and cell morphology. Benzo(a)pyrene $(\mathrm{BaP})$ was used for the induction of lung cancer in experimental rats, and atorvastatin $(5,10$, and $20 \mathrm{mg} / \mathrm{kg}$ body weight) was used for treatment in a dosedependent manner. Body weight and lung tumors were calculated at regular intervals. Antioxidants, proinflammatory cytokines, phase I and II antioxidant enzymes, polyamine enzymes, and apoptosis markers were determined at end of the experimental study.

Results: Cell cycle arrest occurred at the G2/M phase after atorvastatin treatment. Atorvastatin increased cytochrome $\mathrm{C}$ expression and caspase activity in a dose-dependent manner, and increased the activity of antioxidative enzymes, such as GPx, SOD, GST, reduced glutathione, and catalase, and reduced the level of nitrate and LPO. It also altered the xanthine oxidase (XO), Lactic Acid Dehydrogenase (LDH), quinone reductase (QR), UDP-glucuronosyltransferase (UDP-GT), adenosine deaminase (ADA), Aryl hydrocarbon hydroxylase (AHH), 5'-nucleotidase, cytochrome P450, cytochrome B5 and NADPH cytochrome C reductase levels. Atorvastatin was found to modulate polyamine enzyme levels, such as histamine, spermine, spermidine, and putrescine, and significantly $(\mathrm{P}<0.001)$ reduced the pro-inflammatory cytokine levels, such as tumor necrosis factor- $\alpha$. Interleukin (IL)-6 and interleukin-1 $\beta$ (IL-1 $\beta$ ) increased caspase-3 and caspase-9 levels in a dose-dependent manner.

Conclusions: Our findings indicate that atorvastatin can inhibit lung cancer through apoptosis.

Keywords: Atorvastatin; lung cancer; apoptosis; inflammation; caspase

Submitted Oct 30, 2020. Accepted for publication Feb 03, 2021.

doi: $10.21037 /$ atm-20-7770

View this article at: http://dx.doi.org/10.21037/atm-20-7770 


\section{Introduction}

Cancer is a worldwide health problem and the leading cause of death. Chemotherapy treatment is often used for the treatment of different cancers, including lung cancer. Lung cancer is the leading cause of cancer-related death worldwide (1), affecting approximately $9 \%$ of women and $17 \%$ of men, with a mortality rate of $17 \%$. According to epidemiological reports, 2.1 million people are diagnosed with lung cancer and 1.8 million people die from lung cancer every year till 2018 (2), with $80-90 \%$ of patients developing lung cancer due to continuous smoking (3). It is well known that tobacco smoke produces more than 60 cancer-inducing mediators. Of all of the harmful elements of smoke tobacco, benzo(a)pyrene $(\mathrm{BaP})$ plays a significant role in the induction of lung cancer. $\mathrm{BaP}$ metabolizes into benzo(a)pyrene-7,8-diol-9,10-epoxide, which forms DNA, which contributing to expansion of lung cancer disease $(3,4)$. The level of reactive oxygen species (ROS) increases in the lungs due to cigarette smoke and toxins (5). However, chemotherapy-induced toxicity in the normal cells due to differentiation of the synthetic drugs into the cancerous and normal cells (6). Alternative medicine is the best choice to treat the lung cancer, these therapies having effect on the cancerous cells. Alternative medicine has been found to reduce the reactivity of carcinogenic compounds, restore enzymes to promote cancer detoxification, activate mediators, minimize apoptosis, decrease cell proliferation and promote ROS scavenging (7).

Atorvastatin $\left(\left(\mathrm{R}-\left(\mathrm{R}^{*}, \mathrm{R}^{*}\right)\right)\right.$-2-(4-fluorophenyl)-dihydroxy5-(1-methylethyl)-3-phenyl-4-(phenylamino), which has a high molecular weight $(1,209.4)$, is a lipid-lowering agent, which has anticancer potential against different cell lines $(8,9)$.Previous in vitro research has suggested that atorvastatin suppresses the activation of Rho and relapses the metastatic phenotype of melanoma cells through CHL, A375M, WM 166-4, and SK-Mel-28 (8-10). Other studies have suggested that atorvastatin reduces myeloma cells and $\mathrm{B}$ and $\mathrm{T}$ lymphoblastoid cell lines when incubated with the T lymphoblast-like cell lines (e.g., CEM and Jurkat), myeloma cell lines (e.g., U266), and lymphocyte cell lines (e.g., human IM9) (8-10). Additionally, when used in combination with chemotherapeutic agents, such as doxorubicin, atorvastatin can reduce doxorubicin-resistant plasma cell lines (e.g., MCC-2) $(9,11)$. Atorvastatin has also been found to reduce cellular proliferation in colorectal cancer cell lines (e.g., Caco-2) and inhibit the growth of MIA, $\mathrm{PaCa}-2$, and Panc-1 cells (human pancreatic cell lines) $(8,9)$. Due to the antiproliferative and anticancer effect of atorvastatin, in the current experimental study, we used atorvastatin as a chemotherapeutic agent against lung cancer cell lines H460 and A549 (lung cancer cell lines) and in vivo scrutinized against the $\mathrm{BaP}$ induced lung cancer.

We present the following article in accordance with the ARRIVE reporting checklist (available at http://dx.doi. org/10.21037/atm-20-7770).

\section{Methods}

\section{Cell lines}

Human lung cancer cell lines H460 and A549 were procured from the American Cell Culture Laboratory and cultured in RPMI-1640 medium containing FBS (5\%). BEAS-2B (human bronchus epithelial cell lines) were cultured in RPMI-1640 medium containing FBS (10\%).

\section{Cell count}

Cell count was done using an equal amount of cell volume with trypan blue, cell concentration $20 \mu \mathrm{L}$ mixed with 20 $\mu \mathrm{L}$ of trypan blue). A hemocytometer was used to count the number of cells under alight microscope, and the number of cells was calculated using the following equation:

$$
\begin{aligned}
& \text { Cell concentration }\left(\frac{\text { cell }}{m l}\right) \\
& =\text { Dilution times } \times 2 \times \frac{1}{2} \times\left(\frac{A}{18}+\frac{B}{18}\right) \times 10000
\end{aligned}
$$

where $\mathrm{A}$ and $\mathrm{B}$ are the total number of cells in both the lower and upper measurement chambers, respectively, depending on identical measures (9 squares).

\section{MTT assay}

To evaluate cell viability, MTT assay was used. Cells were seeded onto 96-well plates at a density of $5 \times 10^{3}$ cells $(0.2 \mathrm{~mL})$ and incubated for $24 \mathrm{~h}$.

\section{Cell cycle analysis}

Cells were seeded onto a culture plate $(6 \mathrm{~cm})$ for the cell cycle analysis and incubated overnight. The culture medium was then substituted and labelled with atorvastatin concentration, and incubated for $48 \mathrm{~h}$. Cells were washed with PBS and collected Trypsin-EDTA treatment. Cells were centrifuged at $1,200 \mathrm{~g}$ rpm for $5 \mathrm{~min}$, completely 
removing the supernatant and flushed with PBS twice; $1 \mathrm{~mL}$ ethanol was then added to stabilize the cells at $4{ }^{\circ} \mathrm{C}$.

\section{Experimental animal}

Experiments were performed under a project license (NO.: 13791864120) granted by institutional ethics committee of Xi'an Central Hospital, in compliance with institutional guidelines for the care and use of animals.

\section{Animal studies}

Swiss Wistar rats were divided into 5 groups and each group contained 12 rats.

Group I comprised normal control rats (that received the $\mathrm{CMC})$, group II comprised the $\mathrm{BaP}$ control rats $(50 \mathrm{mg} / \mathrm{kg}$, body weight), and groups III-V were treated groups; the rats in these groups received $\mathrm{BaP}(50 \mathrm{mg} / \mathrm{kg}$, body weight $)$ and atorvastatin $(5,10$ and $20 \mathrm{mg} / \mathrm{kg}$, body weight), respectively. All the rats received the above-mentioned treatment once daily.

The food and water intake of all groups rats were estimated at regular time interval. The body weight of all rats was measured at regular time intervals. The rats received the treatment for up to 16 weeks.

\section{Lung marker enzymes}

\section{Aryl hydrocarbon hydroxylase}

Previous reported protocol was used for the estimation of aryl hydrocarbon hydroxylase with minor modification (12). Briefly, the serum sample was mixed with the $0.43 \mathrm{mM}$ NAD, $0.37 \mathrm{mM}$ NADP, $2.5 \mathrm{mM}$ glucose-6-phosphate, $0.8 \mathrm{mg} / \mathrm{mL}$ bovine serum albumin, $1 \mathrm{IU} / \mathrm{mL}$ glucose- 6 phosphate dehydrogenase, $50 \mathrm{mM}$ Tris buffer, $0.08 \mathrm{mM}$ $\mathrm{BP}$, and $5 \mathrm{mM} \mathrm{MgCl}_{2}$ soluble in the $20 \mu \mathrm{ll}$ of acetone and incubated at room temperature.

\section{5'-nucleotidase}

The determination of 5 '-nucleotidase was based on a previously reported method (13). Briefly, serum 5 NT activity was determined via subtracting non-specific phosphatase activity with glycerophosphate using as the substrate. The serum sample was mixed with the buffer substrate $(\mathrm{pH} 9.3)$ and water $(0.3 \mathrm{~mL})$, before being incubated at $37^{\circ} \mathrm{C}$ for $2 \mathrm{~h}$. After incubation, the test tube was successfully removed and immediately mixed with trichloroacetic acid (30\%) and allowed for $2 \mathrm{~min}$ and filter.
After developing the color for $15 \mathrm{~min}$, the final absorbance was read at $660 \mathrm{~nm}$.

\section{LDH estimation}

LDH activity was based on its ability to covert lactate to pyruvate in the presence of co-enzymes nicotinamide adenine dinucleotide $\left(\mathrm{NAD}^{+}\right)$; the level of $\mathrm{LDH}$ was expressed U/L in the serum $(14,15)$.

\section{Adenosine deaminase (ADA)}

ADA was calculated via spectrophotometry with minor modifications (16). Briefly, the serum sample was mixed with the phosphate buffer $(\mathrm{pH})$ and incubated at $37^{\circ} \mathrm{C}$ for $15 \mathrm{~min}$. Absorbance was read at $265 \mathrm{~nm}$ to determine the conversion of adenosine into inosine via spectrophotometry technique.

\section{Estimation of antioxidative parameters}

\section{Reduced glutathione (GSH)}

For the determination of GSH, the serum sample was first mixed with the distilled water $(2 \mathrm{~mL})$ and then mixed with glacial metaphosphoric acid $(50.1 \mathrm{mg})$, EDTA (6 mg), and sodium chloride $(0.9 \mathrm{~mL})$. The reaction mixture was incubated at room temperature for $5 \mathrm{~min}$ and immediately filtered using filter paper. The filtrate $(0.5 \mathrm{~mL})$ was collected and mixed with the disodium phosphate $(2 \mathrm{~mL})$; absorbance was read at $412 \mathrm{~nm}$ using a UV spectrophotometer (17).

\section{Superoxide dismutase (SOD)}

For the estimation of SOD, the xanthine-xanthine oxidase system was used to determine the superoxide radical reacts with the iodonitrotetrazolium (INT) radical to generate the colored formazan. The color intensity generated during this reaction was estimated over a 3-min period at a wavelength $505 \mathrm{~nm}$ (18).

\section{Glutathione peroxidase (GPx)}

GPx suppresses the accumulation of hydrogen peroxide in cells and is responsible for removing oxygen radicals via glutathione and glutathione reductase. The calculation of GPx based on the spectrophotometric demonstration of the suppression in NADPH used. The quantity of GPx was determined via using UV spectrophotometer at $340 \mathrm{~nm}$ (17).

\section{Vitamin E}

After collecting serum from blood, serum was transferred 
into the pre incubated tube for saponification and extraction before vitamins $\mathrm{C}$ and $\mathrm{E}$ estimation or kept the sample at $-20{ }^{\circ} \mathrm{C}$. The sample was then rewashed with isotonic buffer (pH 7.4) containing sodium chloride (7.27 g), anhydrous disodium phosphate $(1.42 \mathrm{~g})$, and disodium EDTA $(0.1 \mathrm{~g})$ in $1,000 \mathrm{~mL}$ of distilled water $(15,19)$.

\section{Estimation of phase I enzymes}

\section{Cytochrome P450}

Briefly, the serum sample was mixed with $0.1 \mathrm{M}$ Tris buffer $(\mathrm{pH} 8.5)$ and incubated at $37^{\circ} \mathrm{C}$ for $15-20 \mathrm{~min}$ at $4{ }^{\circ} \mathrm{C}$. The sample was then filtered and finally collected the filtrate and added the sodium deoxycholate and centrifuged at 15,000 $\times \mathrm{g}$ for $1 \mathrm{~h}$ and finally estimated the wavelength at $450 \mathrm{~nm}$ (20).

\section{NADPH cytochrome C reductase}

Nucleotide-cytochrome C reductase activity was estimated using a previously described protocol with minor modifications (21). Briefly, the serum sample mixed with phosphate buffer $(0.33 \mathrm{M})$ and 2,6 dichlorophenolindophenol and incubated at $37^{\circ} \mathrm{C}$ for $60 \mathrm{~min}$; absorbance was read at $550 \mathrm{~nm}$.

\section{Cytochrome b5}

Cytochrome b5 activity was estimated using a previous described protocol with minor modifications (21). Briefly, the serum sample mixed with sucrose $(0.25 \mathrm{M})$ and centrifuged at $6,000 \times \mathrm{g}$ for $10 \mathrm{~min}$. Tris buffer $(0.5 \mathrm{M})$ was then added at $\mathrm{pH} 7.6$; absorbance was read at $550 \mathrm{~nm}$.

\section{UDP-glucuronyltransferase}

UDP-glucuronyltransferase activity was calculated with $\mathrm{IaC}$ morphine as substrate via following the previous method with minor modifications. Briefly, the UDPGA $(1.5 \mathrm{mM})$ and morphine $(15 \mathrm{mM})$ was taken and finally determined the absorbance via the ultraviolet spectroscopy (22).

\section{Glutathione S-transferases}

The serum sample was mixed with the guanidine hydrochloride (6Molor) containing 2-mercaptoethanol $(10 \mathrm{mM})$.Potassium phosphate $(50 \mathrm{mM})$ was then added at $\mathrm{pH} 6.7$ and incubated at room temperature for $24 \mathrm{~h}$; absorbance was read at $650 \mathrm{Nm}$ (23).

\section{Estimation of neuron specific enolase (NSE) carcinoembryonic antigen (CEA) NSE}

The level of NSE and CEA was estimated in the blood serum by using the chemiluminescent immunoassay (fully automated ADVIA Centaur, Bayer Chemiluminescence System, Thermo Fisher Scientific, USA).

\section{Estimation of pro-inflammatory cytokines}

Rat pro-inflammatory cytokine kits were used to estimate pro-inflammatory cytokines, such as interleukin (IL)-6, IL- $1 \beta$ and tumor necrosis factor- $\alpha$ (TNF- $\alpha$; Xitang Bio-Technology, Shanghai, China) according to the manufacturer's instructions.

\section{Estimation of inflammatory and apoptosis marker}

The inflammatory parameters such as COX and NF-кB were estimated by using the standard available kits. The apoptosis such as caspase- 3 and caspase- 9 were also estimated by using the available (Xitang Bio-Technology Co., Ltd., Shanghai, China) following the manufacture instructions.

\section{Statistical analysis}

All experiments were performed in triplicate, and the results were expressed to analysis of variance and Duncan's multiple range test for mean contrast validity $(\mathrm{P}<0.05)$.

\section{Results}

\section{Effect of atorvastatin on cell proliferation and GO/G1 phase}

Atorvastatin decreased cell proliferation against the $\mathrm{H} 460$ and A549 cell lines in both a time-and concentrationdependent manner, indicating its anti-proliferative effects (Figure 1). The MTT assay demonstrated that atorvastatin inhibits cell viability (almost 50\%) after $24 \mathrm{~h}$ incubation.

Dose-dependent atorvastatin therapy induced apoptosis, as shown by a decreased proportion of cells in the G2/M phase, although cell aggregation was also observed after $48 \mathrm{~h}$ in the sub-G1 process. As shown in Figure 2, atorvastatin caused cell cycle arrest at the G1 phase against both cell lines.

\section{Effect of atorvastatin on caspase- 3 and caspase- 7 activity}

Caspase- 3 and caspase-7 activity was measured in the 
H460 and A549 cell lines after treatment with atorvastatin for $48 \mathrm{~h}$. Dose-dependent treatment with atorvastatin considerably increased caspase- 3 and caspase- 7 activity, indicating the induction of apoptosis (Figure S1). Figure S2 shows the effect of atorvastatin on cell adhesion.

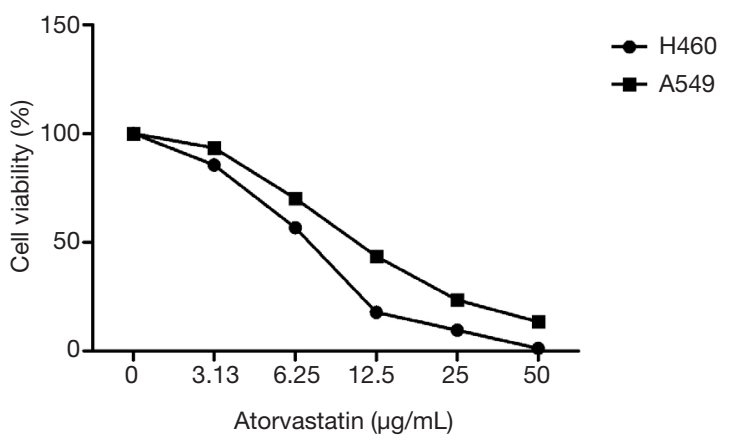

Figure 1 Anti-proliferative effect of atorvastatin on H460 and A549 lung cancer cell lines.

A

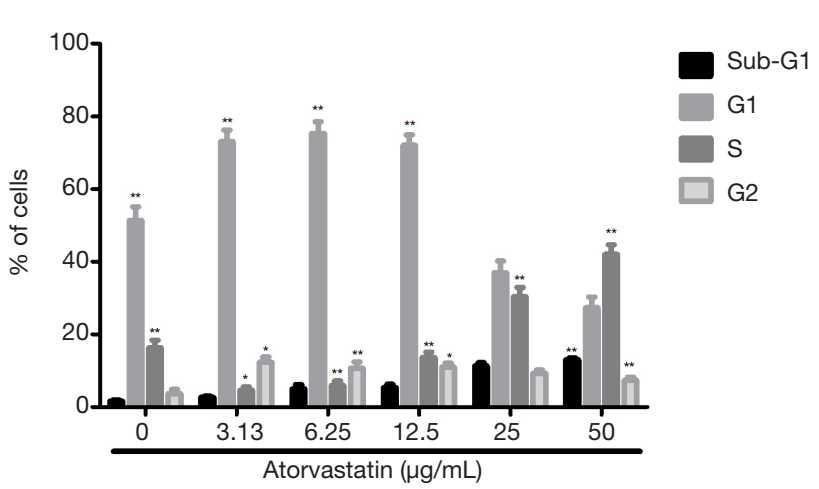

C

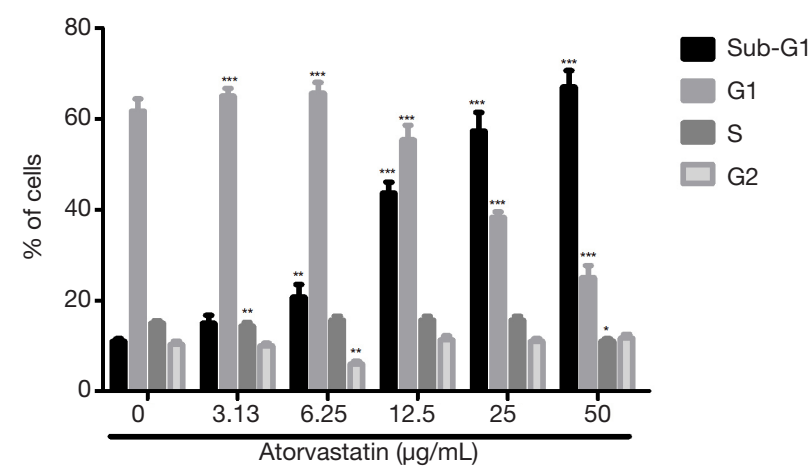

\section{Effect of atorvastatin on body weight and lung weight}

The effect of atorvastatin on body and lung weight in rats was is shown in Table $\mathrm{S} 1$. BaP control group rats had decreased body weight compared to the control rats, and a similar result was observed for lung tissue; results were showed as relative lung tissue ratio to body weight. The concentration-dependent treatment of atorvastatin significantly increased body weight and lung tissue weight compared with $\mathrm{BaP}$ group rats.

\section{Effect of atorvastatin on antioxidative parameters}

In $\mathrm{BaP}$ control rats, SOD, GPx, GST, reduced glutathione, CAT, vitamin E, and vitamin $\mathrm{C}$ levels decreased, whereas nitrate level increased compared with other treated rat groups. The concentration-dependent treatment of atorvastatin significantly $(\mathrm{P}<0.001)$ increased of SOD, GPx, GST, reduced glutathione, CAT, vitamin E, vitamin C, and nitrate levels (Figure 3).

\section{B}

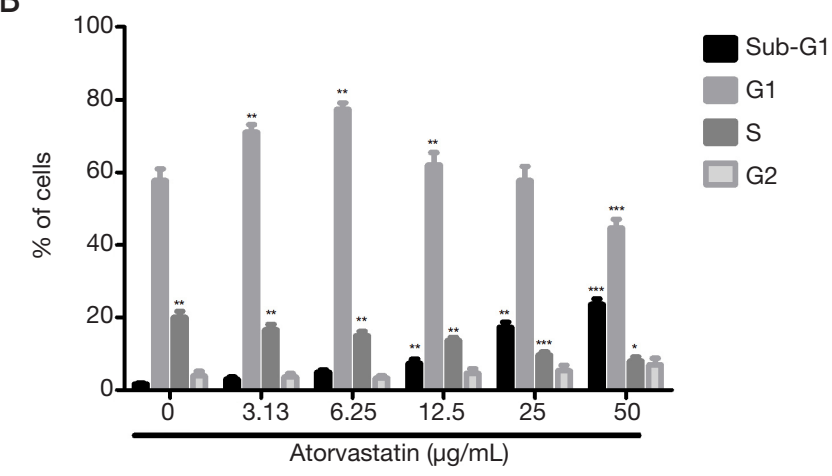

Figure 2 Effect of atorvastatin on H460 and A549 lung cancer cell lines following treatment at different time intervals (12, 24, and 48 h). Data are mean \pm standard error of mean of 3 independent experiments. Student's $t$-test was used for the statistical analysis. ${ }^{*} \mathrm{P}<0.05$, ${ }^{* *} \mathrm{P}<0.01,{ }^{* * *} \mathrm{P}<0.001$. 
A

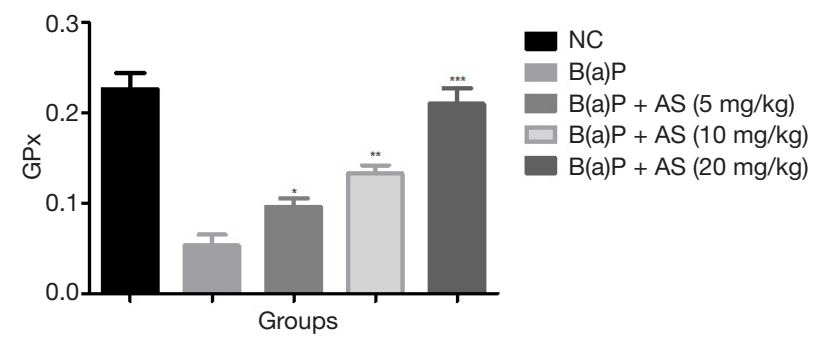

C

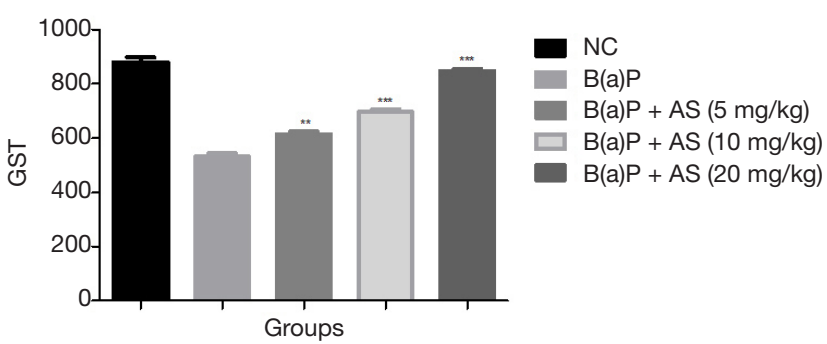

$E$

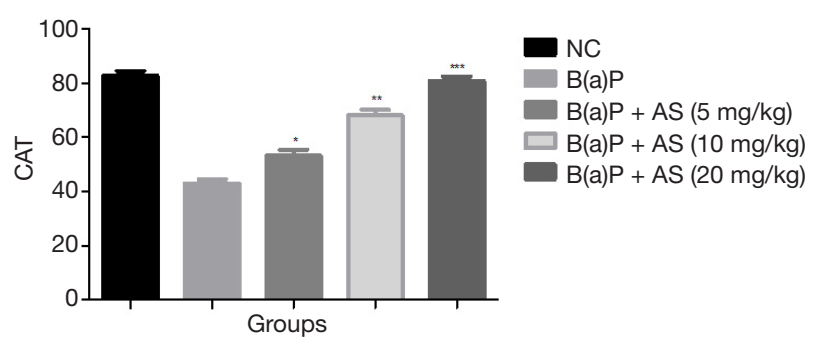

G

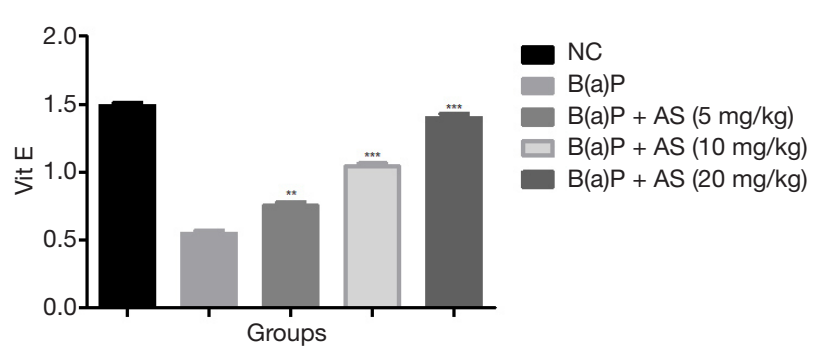

B

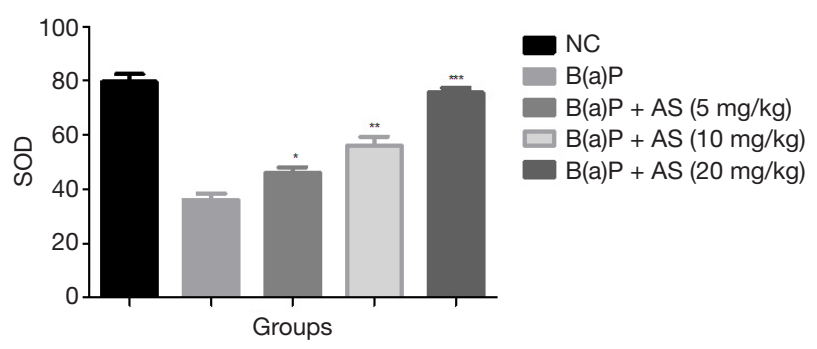

D

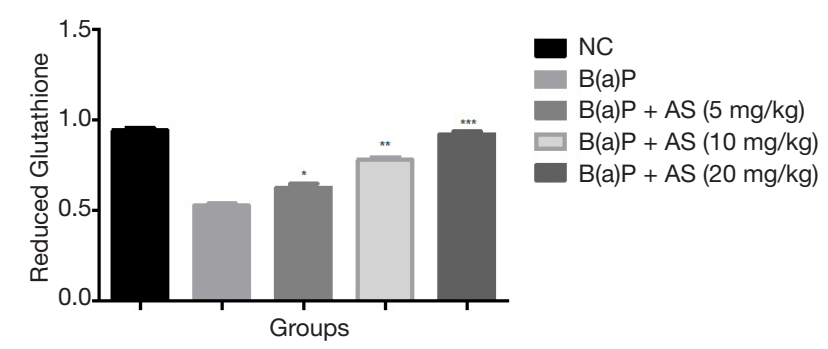

$\mathrm{F}$

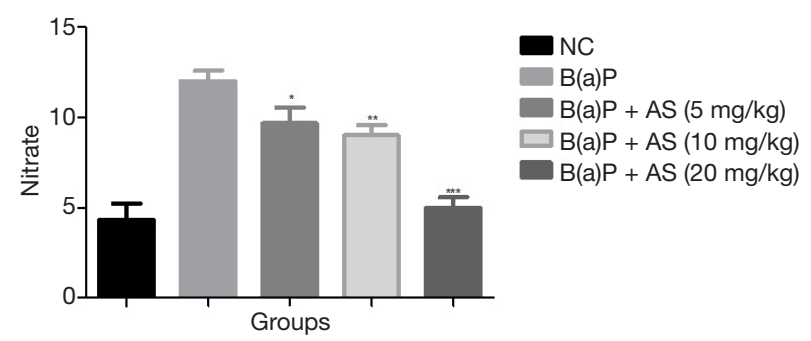

$\mathrm{H}$

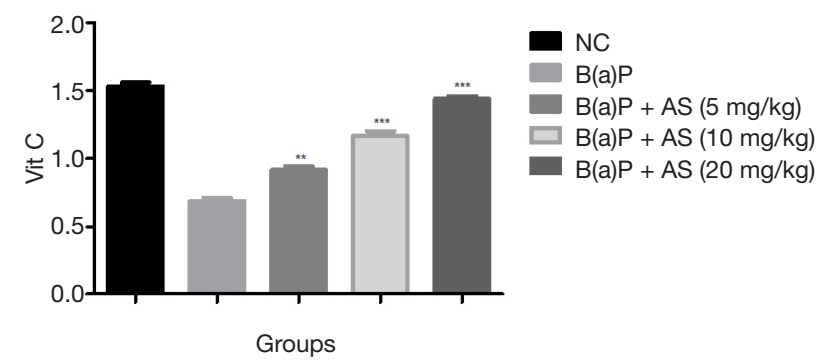

Figure 3 Effect of atorvastatin on antioxidant parameters against benzo(a)pyrene (BaP)-induced lung cancer. (A) Glutathione peroxidase, (B) superoxide dismutase, (C) glutathione S-transferase, (D) reduced glutathione, (E) catalase, (F) nitrate, (G) vitamin E (Vit E), (H) vitamin C (Vit C). Bonferroni test was used for the statistical analysis. All tested groups compared with the $\mathrm{BaP}$ group. ${ }^{*} \mathrm{P}<0.05,{ }^{* *} \mathrm{P}<0.01,{ }^{* * *} \mathrm{P}<0.001$. NC, normal control.

\section{Effect of atorvastatin on biochemical parameters and phase I enzymes}

Increased levels of $\mathrm{XO}, \mathrm{LPO}, \mathrm{LDH}, \mathrm{ADA}, \mathrm{AHH}$, and 5 '-nucleotide, and reduced levels of QR and UDP-GT in the $\mathrm{BaP}$ induced control group rats are shown in Figure 4. Treatment with atorvastatin significantly $(\mathrm{P}<0.001)$ downregulated XO, LPO, LDH, ADA, AHH, and 5'-nucleotide levels, and upregulated QR and UDP-GT 
A

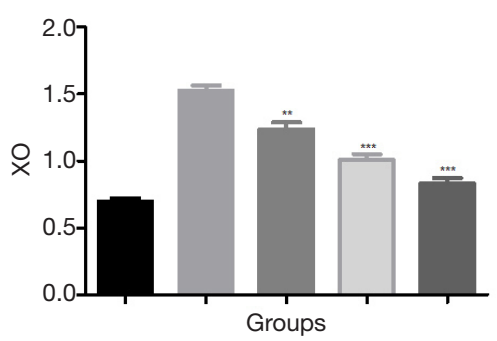

C

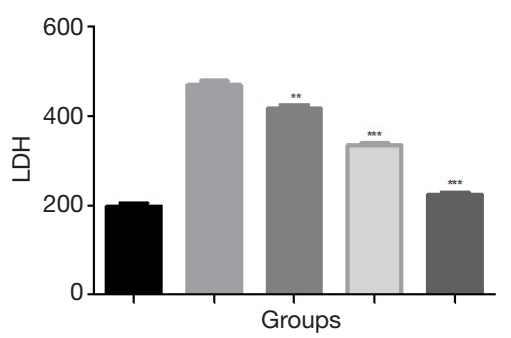

$E$

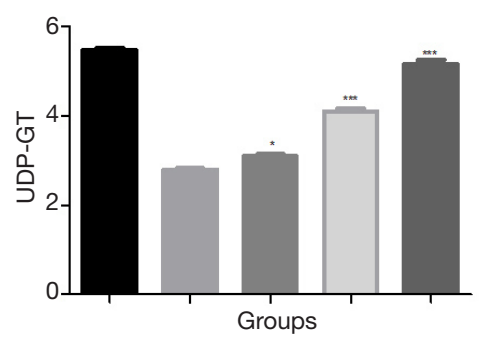

G

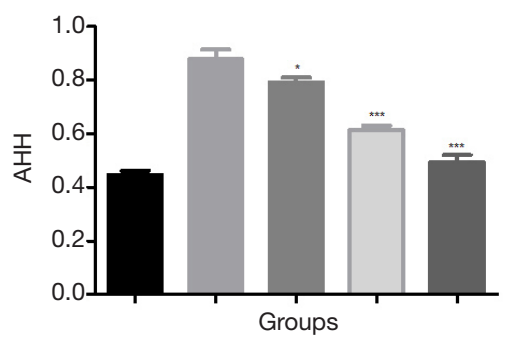

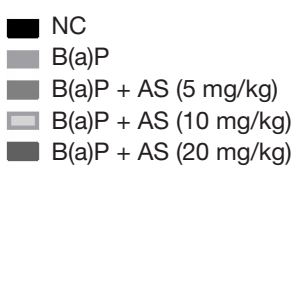

B

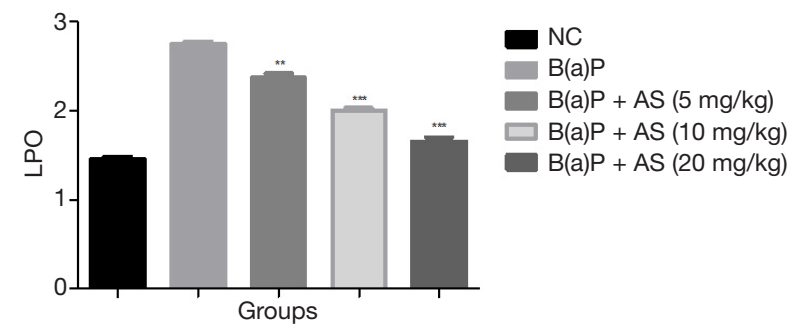

D

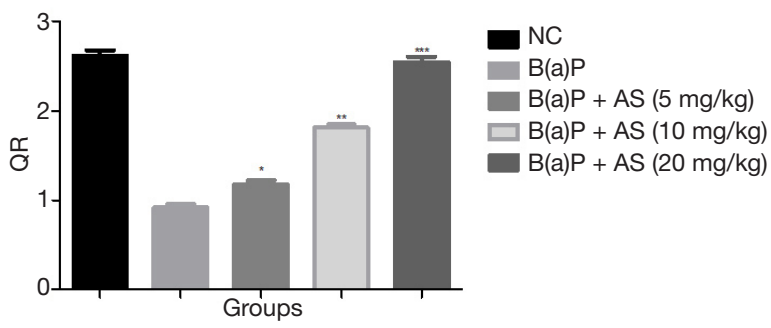

$\mathrm{F}$

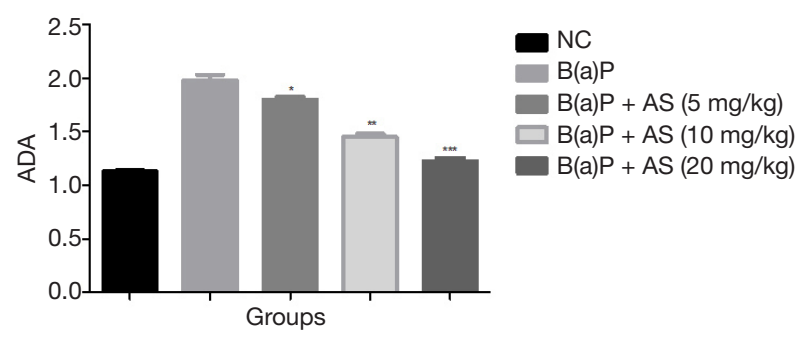

Figure 4 Effect of atorvastatin on phase I and II enzymes on benzo(a)pyrene (BaP)-induced lung cancer. (A) Xanthine oxidase, (B) lipid peroxidation, (C) lactose dehydrogenase, (D) quinine reductase, (E) UDP-glucuronosyltransferase, (F) adenosine deaminase, (G) aryl hydrocarbon hydroxylase, $(\mathrm{H}) 5^{\prime}$-nucleotidase. Bonferroni test was used for the statistical analysis. All tested groups compared with the BaP group. ${ }^{*} \mathrm{P}<0.05,{ }^{* *} \mathrm{P}<0.01,{ }^{* * *} \mathrm{P}<0.001 . \mathrm{NC}$, normal control.

levels in a dose-dependent manner compared with BaPinduced lung cancer control group rats.

Phase I enzymes, such as cytochrome b5, cytochrome $\mathrm{P} 450$, and NADPH cytochrome C reductase, showed increased levels in BaP-induced lung cancer group rats.
The administration of atorvastatin in the $\mathrm{BaP}$ control rats significantly $(\mathrm{P}<0.001)$ reduced the levels of phase $\mathrm{I}$ enzymes, including cytochrome b5, cytochrome P450, and $\mathrm{NADPH}$ cytochrome $\mathrm{C}$ reductase, in a dose-dependent manner (Figure 5). 
A

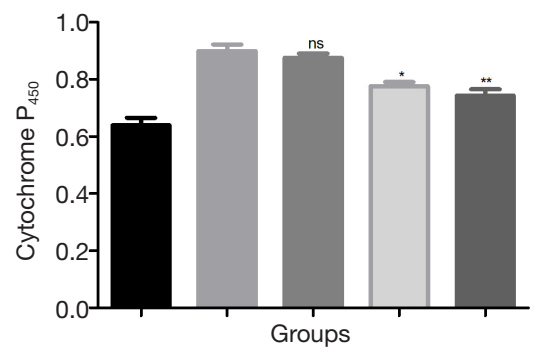

NC

$B(a) P$

$B(a) P+A S(5 \mathrm{mg} / \mathrm{kg})$

$\square \mathrm{B}(\mathrm{a}) \mathrm{P}+\mathrm{AS}(10 \mathrm{mg} / \mathrm{kg})$

$B(a) P+A S(20 \mathrm{mg} / \mathrm{kg})$
B

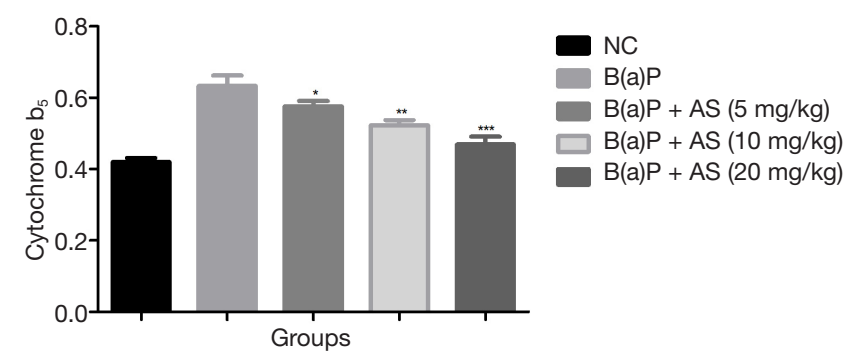

C

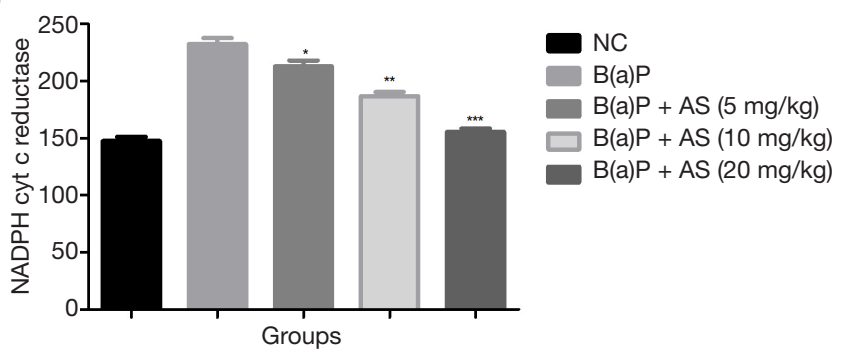

Figure 5 Effect of atorvastatin on phase I enzymes against benzo(a)pyrene (BaP)-induced lung cancer. (A) Cytochrome $\mathrm{P}_{450}$, (B) cytochrome $\mathrm{B}_{5}$, (C) NADPH cytochrome $\mathrm{C}$ (cyt C) reductase. Bonferroni test was used for the statistical analysis. All tested groups compared with the BaP group. ${ }^{*} \mathrm{P}<0.05,{ }^{* *} \mathrm{P}<0.01,{ }^{* *} \mathrm{P}<0.001$. NC, normal control.

A

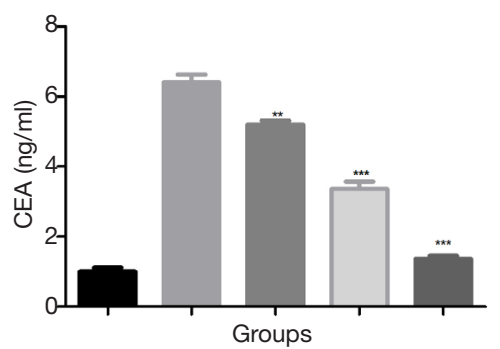

B

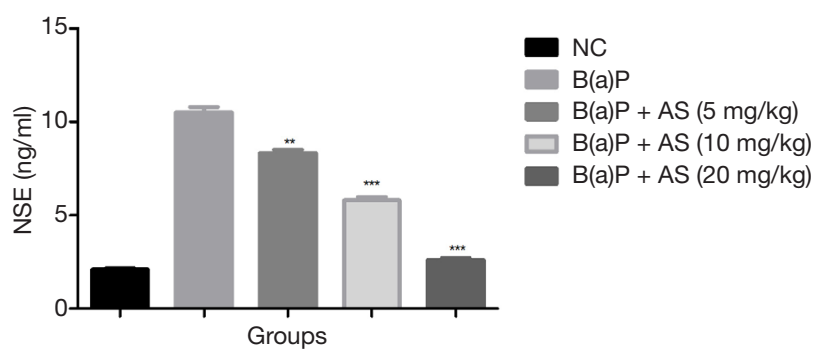

Figure 6 Showed the effect of atorvastatin on lung cancer marker on benzo(a)pyrene (BaP) induced lung cancer. (A) CEA and (B) NSE. For the statically analysis via using the Bonferroni test. All the tested group compared with $\mathrm{B}(\mathrm{a}) \mathrm{P}$ group. ${ }^{* *} \mathrm{P}<0.01,{ }^{* * *} \mathrm{P}<0.001$.

\section{Effect of atorvastatin on NSE, CEA, and polyamine}

In the $\mathrm{BaP}$ control rats, significantly increased levels of NSE and CEA were seen, and concentration-dependent atorvastatin treatment significantly $(\mathrm{P}<0.001)$ decreased NSE and CEA levels (Figure 6).

In the $\mathrm{BaP}$ control rats, increased levels of polyamine enzymes, such as histamine, spermine, spermidine, and putrescine, were downregulated after the concentrationdependent treatment of atorvastatin (Figure 7).

\section{Effect of atorvastatin on pro-inflammatory cytokines and apoptosis markers}

The $\mathrm{BaP}$ control rats had an increased level of proinflammatory cytokines, including IL-1 $\beta$, IL-6, and TNF- $\alpha$, and the dose-dependent treatment of atorvastatin significantly $(\mathrm{P}<0.001)$ reduced the level of proinflammatory cytokines (Figure 8 ).

The dose-dependent treatment of atorvastatin significantly $(\mathrm{P}<0.001)$ increased the level of pro- 
A

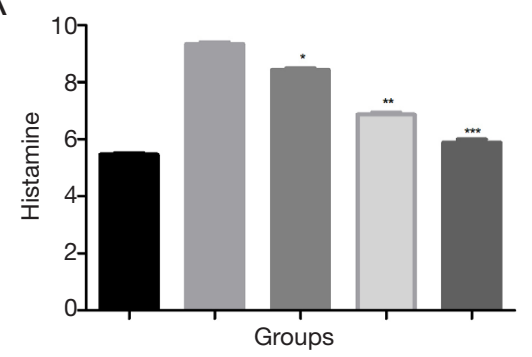

C

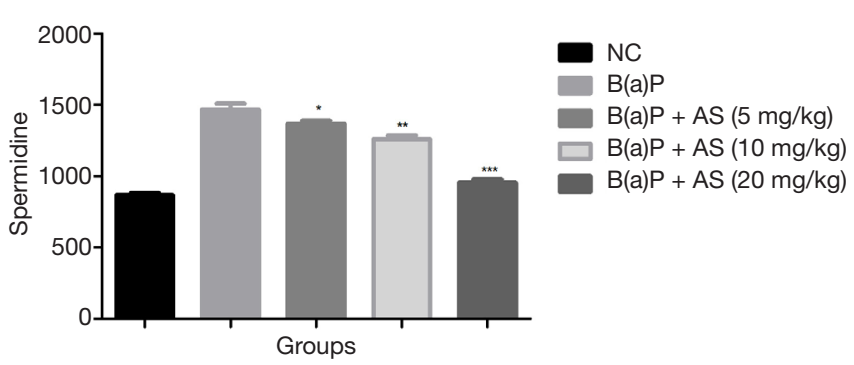

B

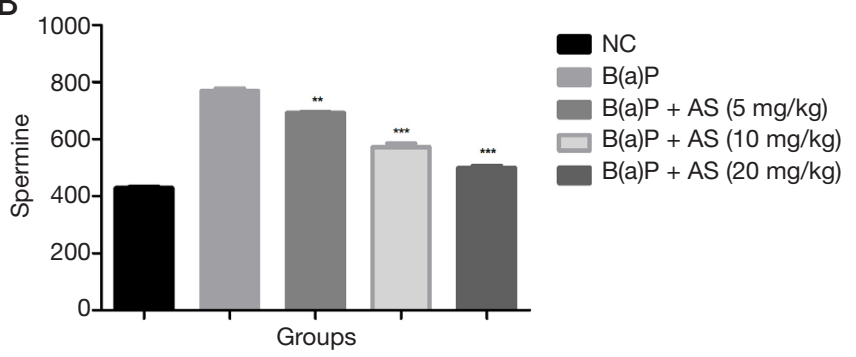

$\mathrm{D}$

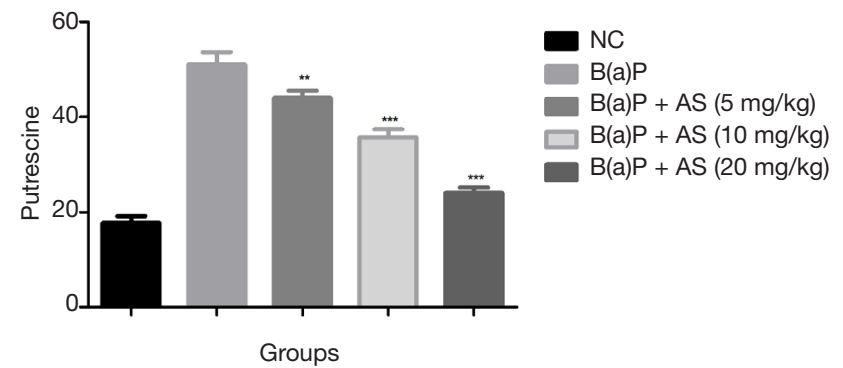

Figure 7 The effect of atorvastatin on polyamine enzymes on benzo(a)pyrene (BaP)-induced lung cancer. (A) histamine, (B) spermine, (C) spermidine, (D) putrescine. Bonferroni test was used for the statistical analysis. All tested groups compared with the $\mathrm{BaP}$ group. ${ }^{*} \mathrm{P}<0.05$, ${ }^{* *} \mathrm{P}<0.01,{ }^{* * *} \mathrm{P}<0.001$. AS, atorvastatin; $\mathrm{NC}$, normal control.

inflammatory cytokines, similar manner of normal control group rats (Figure 9).

\section{Effect of atorvastatin on mRNA expression}

The $\mathrm{BaP}$ control rats showed increased expression of Bax andcaspase-3, and reduced expression of Bcl-2. The concentration-dependent treatment of atorvastatin significantly $(\mathrm{P}<0.001)$ reduced the expression of Bax and caspase-3, and increased Bcl-2 activity (Figure 10).

\section{Discussion}

In the present study, we analyzed both synthetic and natural products as protective cancer drugs (24). Previous research has suggested that atorvastatin has an anticancer effect against various cancers (25). In the present experimental study, we investigated the cytotoxic activity of atorvastatin against lung cancer cell lines A549 and H460. Atorvastatin was found to have cytotoxic and antiproliferative effects against both cell lines in a concentration-dependent manner.

Caspase plays an important role in the implementation of apoptosis induced via stimulations (26). Caspase-3 is an apoptosis marker that is responsible for break the different substrates to form the DNA fragmentation (27). During lung cancer, the caspase level decreases, and tested drug increased the activation of caspase-3 (28). Apoptosis is a controlled cell death that retains cellular homeostasis between cell death and cell division. In the current study, we observed enhanced cleaved caspase- 3 activation,

It is well documented that tumor markers play an imperative role in tumor growth and researcher target the tumor markers to inhibit the tumor growth $(29,30)$. CEA is considered an important marker of cancer, and its acts as a prognostic indicator of lung cancer (31). CEA is often prompted in the excess of outside cell to the malignant epithelial tumor cell and it may provide the strength to the other non-malignant cells and increases the metastasis $(2,4)$. Cancer markers, such as NSE, is called as the intracellular enzymes. The level of NSE is estimated in the serum and is also considered a marker of lung cancer $(2,4)$.

The level of NSE boosted in the $\mathrm{BaP}$ and atorvastatin significantly decreased the level of NSE and CEA and suggesting the chemoprotective effect of atorvastatin.

Antioxidative mechanisms play an important role to inhibit the progression of cancer (32). During cancer, free radicals increase, and endogenous antioxidants remove excess free radicals. The continuous generation of free radicals increase oxidative stress. Evidence indicates that 
A

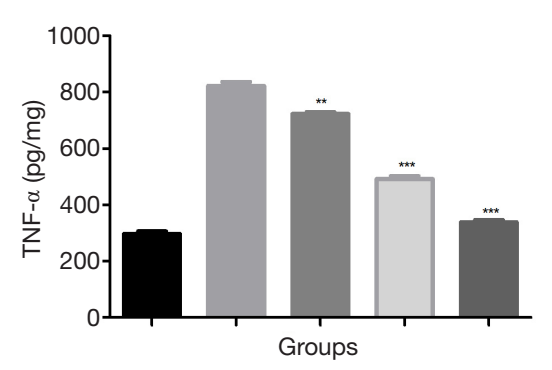

C

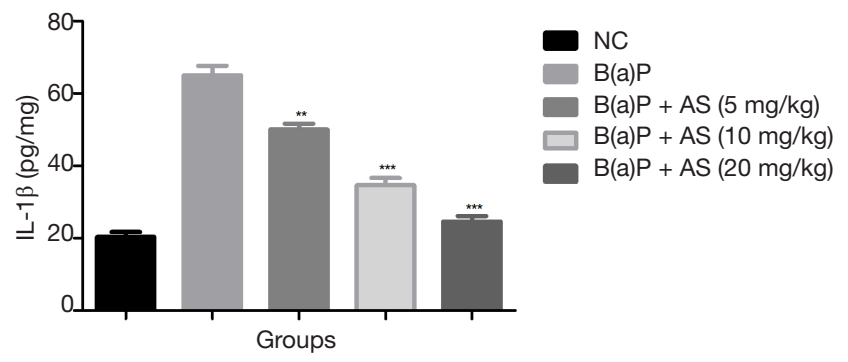

B

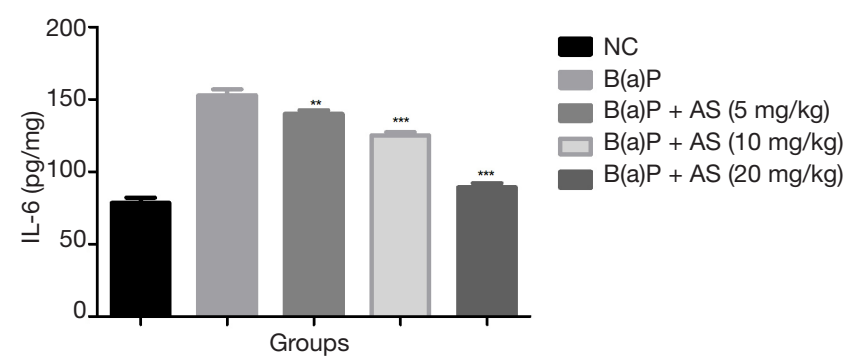

Figure 8 Effect of atorvastatin on pro-inflammatory cytokines against benzo(a)pyrene (BaP)-induced lung cancer. (A) Tumor necrosis factor- $\alpha$ (TNF- $\alpha$ ), (B) interleukin (IL)-6, (C) IL-1 . Bonferroni test was used for the statistical analysis. All tested groups compared with the BaP group. ${ }^{* *} \mathrm{P}<0.01,{ }^{* * *} \mathrm{P}<0.001$. NC, normal control.

\section{A}

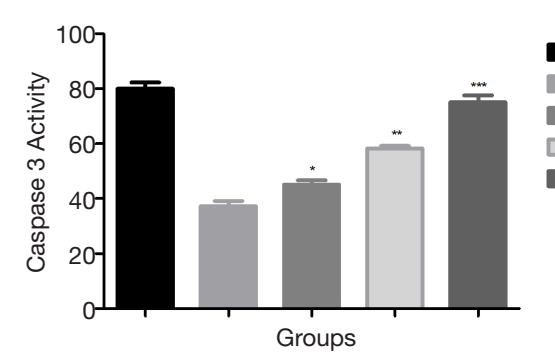

B

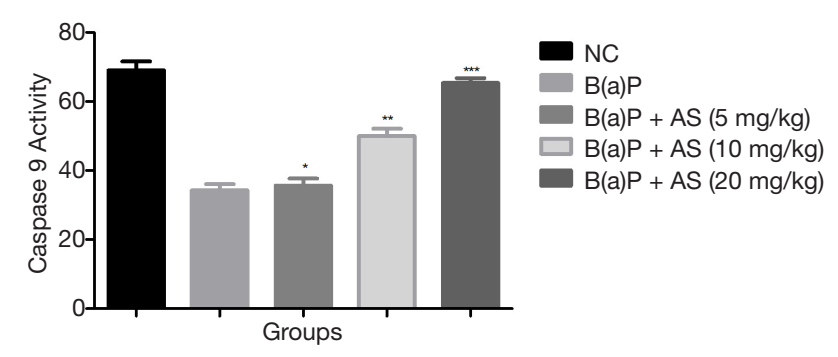

Figure 9 Effect of atorvastatin on caspase marker on benzo(a)pyrene (BaP)-induced lung cancer. (A) Caspase-3, (B) caspase-9. Bonferroni test was used for the statistical analysis. All tested groups compared with the $\mathrm{BaP}$ group. ${ }^{*} \mathrm{P}<0.05,{ }^{* *} \mathrm{P}<0.01,{ }^{* * *} \mathrm{P}<0.001$. AS, atorvastatin; NC, normal control.

oxidative stress is responsible for various human diseases, including cancer $(32,33)$. Endogenous antioxidants, such as SOD and CAT, are first-line endogenous antioxidants that are scavenge the free radicals such as superoxide $\left(\mathrm{O}_{2}\right)$, hydroxyl radical and many more (32). The deposition of excess $\mathrm{H}_{2} \mathrm{O}_{2}$ in tissue has toxic effects on cells. GR (GPx substrate) decreases the significance of singlet oxygen and hydroxyl radicals. Due to the increase of antioxidative enzymes in cells, it can protect cells from free radical attack $(32,34)$. In the present study, during BaP-induced lung cancer, the rats had an increased level of the above mentioned antioxidant enzymes (SOD, CAT and GSH, and the dose-dependent treatment of atorvastatin significantly increased the level of endogenous antioxidants. Moreover, it can be concluded that the atorvastatin treatment protects the tissue and normal cells against the cytotoxic effects of $\mathrm{BaP}$.

During lung cancer and other types of neoplasms, the level of ADA increases (4). Another lung cancer marker, AHH (a cell surface enzyme), destroys extracellular glutathione, improving the intracellular glutathione 
A

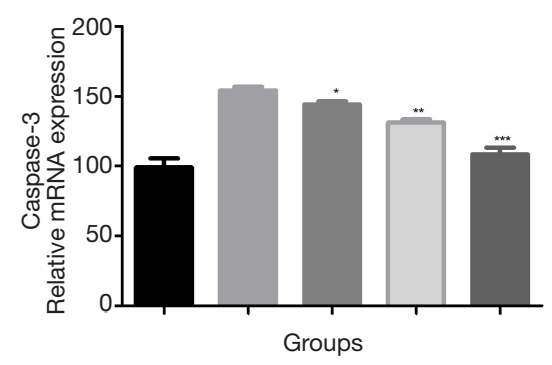

C

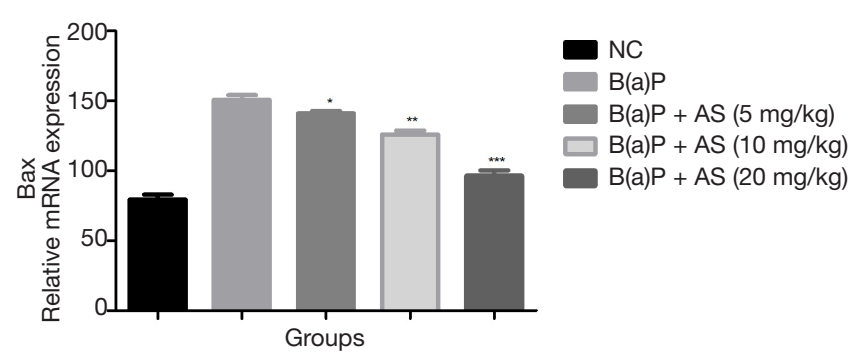

B

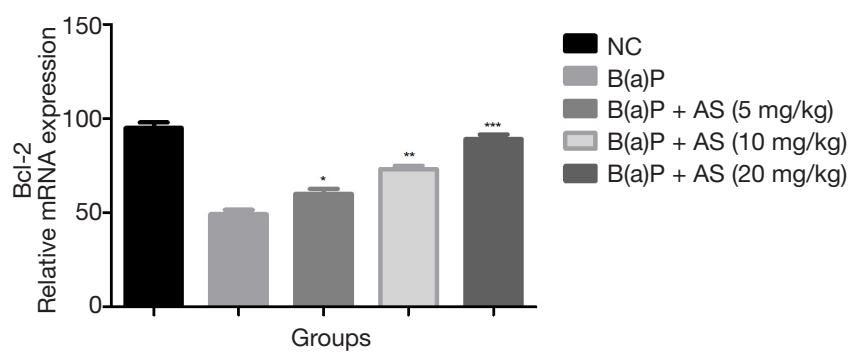

Figure 10 Effect of atorvastatin on apoptosis marker expression against benzo(a)pyrene (BaP)-induced lung cancer. (A) Caspase-3, (B) Bcl-2, (C) Bax. Bonferroni test was used for the statistical analysis. All tested groups compared with the $\mathrm{BaP}$ group. ${ }^{*} \mathrm{P}<0.05,{ }^{* *} \mathrm{P}<0.01,{ }^{* * *} \mathrm{P}<0.001$. AS, atorvastatin; NC, normal control.

synthesized components and making it an effective marker for the early detection of lung cancer $(2,4)$. Enhanced activity of 5'-nucleotide phosphodiesterase has been found to originate from proliferating tumor cells. An increased level of 5'-nucleotide was observed in the lung tumors. $\mathrm{LDH}$ activity was found to be greater in the lung cancer cell lines compared with normal cells. This could be due to the increase in lung LDH activity as a result of increased glycolysis during tumor growth and may also be related to the overgeneration of tumor cells or isoenzyme secretion from injured tissue $(2,4)$. We found that all markers were significantly increased during $\mathrm{BaP}$-induced lung cancer, and the dose-dependent treatment of atorvastatin significantly reduced, indicating chemoprotective effects.

It is well known that cytokines play an imperative role in host defense and pathophysiology under inflammatory conditions $(9,14)$. During the cancer, increase the load of oxidative stress in the tissue and increased oxidative stress start the enhance the inflammatory reaction via increase the pro-inflammatory cytokines (9). BaP increases the concentration of pro-inflammatory cytokines, such as IL$1 \beta$, IL-6, and TNF- $\alpha$, and increases the inflammatory reaction (14). Previous research suggests that cytochrome $\mathrm{C}$ is secreted into the cytosol from the mitochondria and enhances the expression of caspase-3. In the current experimental study, $\mathrm{BaP}$ increased the pro-inflammatory cytokines caspase- 3 and Bax, and reduced the expression of Bcl-2. The dose-dependent treatment of atorvastatin downregulated pro-inflammatory cytokines caspase-3, Bax, and upregulated Bcl-2 expression $(4,14)$.

\section{Conclusions}

Based on the findings of the present study, atorvastatin induces cell death related to cell cycle regulation and cell apoptosis. Atorvastatin can decrease lung carcinogenesis induced via $\mathrm{BaP}$ by reducing cytokines, free radical, oxidative stress, and pro-apoptotic factors. Atorvastatin considerably reduced the cytokines and oxidative stress. On the basis of result, we can say that atorvastatin is the best choice for the treatment of lung cancer.

\section{Acknowledgments}

Funding: Shaanxi Key Research and Development Program: 2018SF-267.

\section{Footnote}

Reporting Checklist: The authors have completed the 
ARRIVE reporting checklist. Available at http://dx.doi. org/10.21037/atm-20-7770

Data Sharing Statement: Available at http://dx.doi. org/10.21037/atm-20-7770

Conflicts of Interest: All authors have completed the ICMJE uniform disclosure form (available at http://dx.doi. org/10.21037/atm-20-7770). The authors have no conflicts of interest to declare.

Ethical Statement: The authors are accountable for all aspects of the work in ensuring that questions related to the accuracy or integrity of any part of the work are appropriately investigated and resolved. Experiments were performed under a project license (NO.: 13791864120) granted by institutional ethics committee of Xi'an Central Hospital, in compliance with institutional guidelines for the care and use of animals.

Open Access Statement: This is an Open Access article distributed in accordance with the Creative Commons Attribution-NonCommercial-NoDerivs 4.0 International License (CC BY-NC-ND 4.0), which permits the noncommercial replication and distribution of the article with the strict proviso that no changes or edits are made and the original work is properly cited (including links to both the formal publication through the relevant DOI and the license). See: https://creativecommons.org/licenses/by-nc-nd/4.0/.

\section{References}

1. Zaorsky NG, Churilla TM, Egleston BL, et al. Causes of death among cancer patients. Ann Oncol 2017;28:400-7.

2. Denissenko MF, Pao A, Tang MS, et al. Preferential formation of benzo[a]pyrene adducts at lung cancer mutational hotspots in P53. Science 1996;274:430-2.

3. Memmott RM, Mercado JR, Maier CR, et al. Metformin prevents tobacco carcinogen-induced lung tumorigenesis. Cancer Prev Res (Phila) 2010;3:1066-76.

4. Stabile LP, Rothstein ME, Cunningham DE, et al. Prevention of tobacco carcinogen-induced lung cancer in female mice using antiestrogens. Carcinogenesis 2012;33:2181-9.

5. Meuwissen R, Berns A. Mouse models for human lung cancer. Genes Dev. 2005;19:643-64.

6. Browder T, Butterfield CE, Kräling BM, et al. Antiangiogenic scheduling of chemotherapy improves efficacy against experimental drug-resistant cancer. Cancer Res 2000;60:1878-86.

7. Mansky PJ, Wallerstedt DB. Complementary medicine in palliative care and cancer symptom management. Cancer J 2006;12:425-31.

8. Simopoulou T, Malizos KN, Poultsides L, et al. Protective effect of atorvastatin in cultured osteoarthritic chondrocytes. J Orthop Res 2010;28:110-5.

9. Hosseinzadeh A, Bahrampour Juybari K, Kamarul T, et al. Protective effects of atorvastatin on high glucose-induced oxidative stress and mitochondrial apoptotic signaling pathways in cultured chondrocytes. J Physiol Biochem 2019;75:153-62.

10. Hartog A, Smit HF, Van Der Kraan PM, et al. In vitro and in vivo modulation of cartilage degradation by a standardized Centella asiatica fraction. Exp Biol Med (Maywood) 2009;234:617-23.

11. Juybari KB, Hosseinzadeh A, Sharifi AM. Protective effects of atorvastatin against high glucose-induced nuclear factor- $\mathrm{\kappa B}$ activation in cultured C28I2 chondrocytes. J Recept Signal Transduct Res 2019;39:1-8.

12. Van Cantfort J, De Graeve J, Gielen JE. Radioactive assay for aryl hydrocarbon hydroxylase. Improved method and biological importance. Biochem Biophys Res Commun 1977;79:505-12.

13. Sotil EU, Jensen DM. Serum enzymes associated with cholestasis. Clin Liver Dis 2004;8:41-54.

14. Kamaraj S, Ramakrishnan G, Anandakumar P, et al. Antioxidant and anticancer efficacy of hesperidin in benzo(a)pyrene induced lung carcinogenesis in mice. Invest New Drugs 2009;27:214-22.

15. Rajendran P, Ekambaram G, Sakthisekaran D. Cytoprotective effect of mangiferin on benzo(a)pyreneinduced lung carcinogenesis in Swiss albino mice. Basic Clin Pharmacol Toxicol 2008;103:137-42.

16. Baggott JE, Vaughn WH, Hudson BB. Inhibition of 5-aminoimidazole-4-carboxamide ribotide transformylase, adenosine deaminase and 5'-adenylate deaminase by polyglutamates of methotrexate and oxidized folates and by 5 -aminoimidazole-4-carboxamide riboside and ribotide. Biochem J 1986;236:193-200.

17. Rahman I, Kode A, Biswas SK. Assay for quantitative determination of glutathione and glutathione disulfide levels using enzymatic recycling method. Nat Protoc 2006;1:3159-65.

18. Ukeda H, Maeda S, Ishii T, et al. Spectrophotometric assay for superoxide dismutase based on tetrazolium salt 3'-\{1-[(phenylamino)-carbonyl]-3,4-tetrazolium\}-bis(4- 
methoxy-6- nitro)benzenesulfonic acid hydrate reduction by xanthine-xanthine oxidase. Anal Biochem 1997;251:206-9.

19. Selvendiran K, Banu SM, Sakthisekaran D. Protective effect of piperine on benzo(a)pyrene-induced lung carcinogenesis in Swiss albino mice. Clin Chim Acta 2004;350:73-8.

20. Omura T, Sato R. The Carbon Monoxide-Binding Pigment of Liver Microsomes. I. Evidence for Its Hemoprotein Nature. J Biol Chem 1964;239:2370-8.

21. Phillips AH, Langdon RG. Hepatic triphosphopyridine nucleotide-cytochrome c reductase: isolation, characterization, and kinetic studies. J Biol Chem 1962;237:2652-60.

22. Pacifici GM, Eriksson LC, Glaumann H, et al. Profile of drug metabolizing enzymes in the nuclear and microsomal fractions from rat liver nodules and normal liver. Arch Toxicol 1988;62:336-40.

23. Habig WH, Pabst MJ, Jakoby WB. Glutathione S-transferase AA from rat liver. Arch Biochem Biophys 1976;175:710-6.

24. Jang M, Cai L, Udeani GO, et al. Cancer chemopreventive activity of resveratrol, a natural product derived from grapes. Science 1997;275:218-20.

25. Newman DJ, Cragg GM. Natural Products as Sources of New Drugs from 1981 to 2014. J Nat Prod 2016;79:629-61

26. Kim B, Seo B, Park S, et al. Albumin nanoparticles with synergistic antitumor efficacy against metastatic lung cancers. Colloids Surfaces B Biointerfaces 2017;158:157-66.

Cite this article as: Du X, Li D, Wang G, Fan Y, Li N, Chai L, Li G, Li J. Chemoprotective effect of atorvastatin against benzo(a)pyrene-induced lung cancer via the inhibition of oxidative stress and inflammatory parameters. Ann Transl Med 2021;9(4):355. doi: 10.21037/atm-20-7770
27. Solis LM, Behrens C, Dong W, et al. Nrf2 and Keap1 abnormalities in non-small cell lung carcinoma and association with clinicopathologic features. Clin Cancer Res 2010;16:3743-53.

28. Sztiller-Sikorska M, Jakubowska J, Wozniak M, et al. A non-apoptotic function of caspase-3 in pharmacologicallyinduced differentiation of K562 cells. Br J Pharmacol 2009;157:1451-62.

29. Nakatsu MN, Ding Z, Ng MY, et al. Wnt/ $/$-catenin signaling regulates proliferation of human cornea epithelial stem/progenitor cells. Invest Ophthalmol Vis Sci 2011;52:4734-41.

30. Chau WK, Ip CK, Mak ASC, et al. C-Kit mediates chemoresistance and tumor-initiating capacity of ovarian cancer cells through activation of $\mathrm{Wnt} / \beta$-catenin-ATPbinding cassette G2 signaling. Oncogene 2013;32:2767-81.

31. Abdelaziz HM, Gaber M, Abd-Elwakil MM, et al, Inhalable particulate drug delivery systems for lung cancer therapy: Nanoparticles, microparticles, nanocomposites and nanoaggregates. J. Control. Release 2018;269:374-92

32. Sayin VI, Ibrahim MX, Larsson E, et al. Cancer: Antioxidants accelerate lung cancer progression in mice. Sci Transl Med 2014;6:221ra15.

33. Mendelsohn AR, Larrick JW. Paradoxical effects of antioxidants on cancer. Rejuvenation Res 2014;17:306-11.

34. Le Gal K, Ibrahim MX, Wiel C, et al. Antioxidants can increase melanoma metastasis in mice. Sci Transl Med 2015;7:308re8. 
A

H460

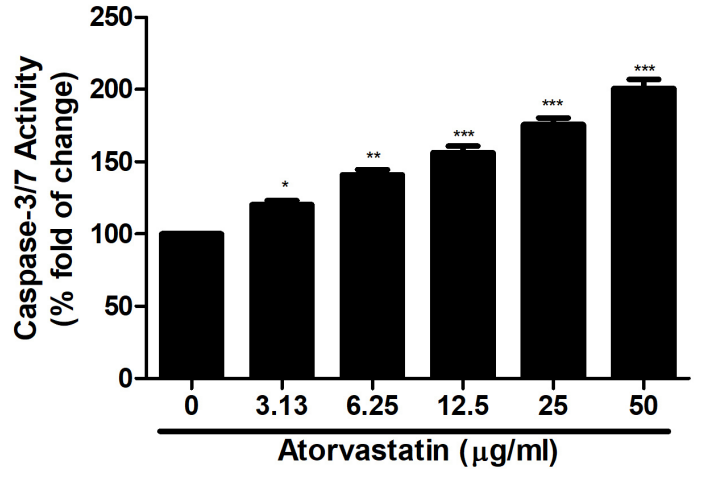

A549

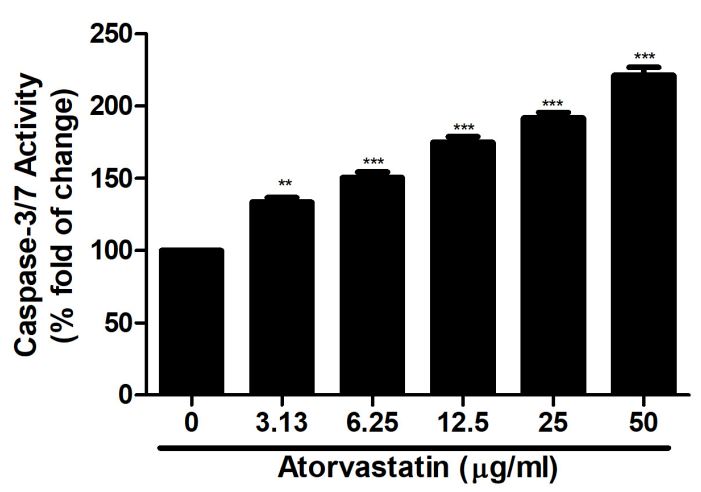

B

H460

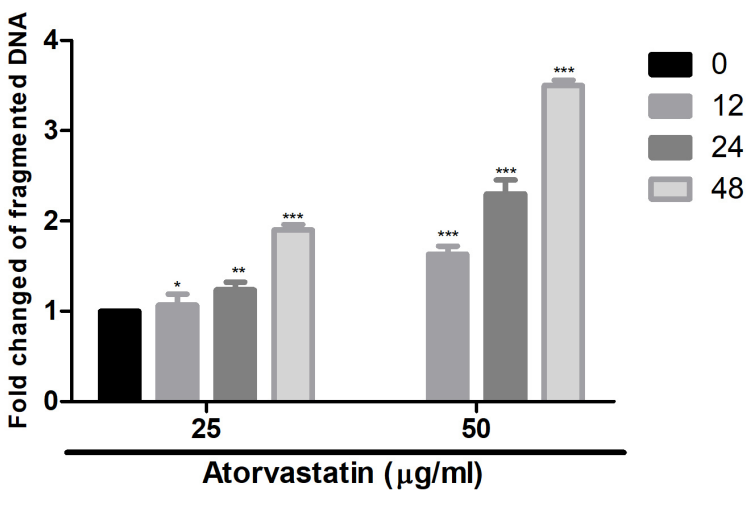

A549

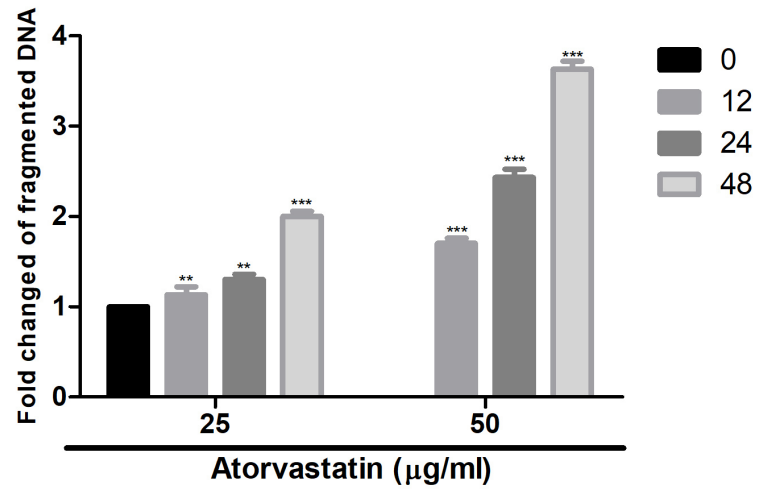

Figure S1 showed the effect of atorvastatin on caspase- 3 and casepase-7 activity and DNA fragmentation on H460 and A549 lung cancer cell lines. Data are mean \pm standard error of mean of 3 independent experiments. Student's t-test was used for statically analysis. ${ }^{*} \mathrm{P}<0.05$, ${ }^{* *} \mathrm{P}<0.01,{ }^{* * *} \mathrm{P}<0.001$.

A

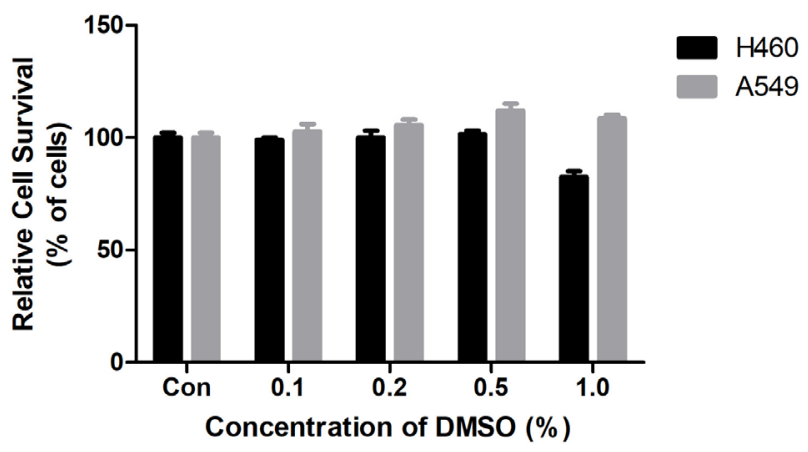

B

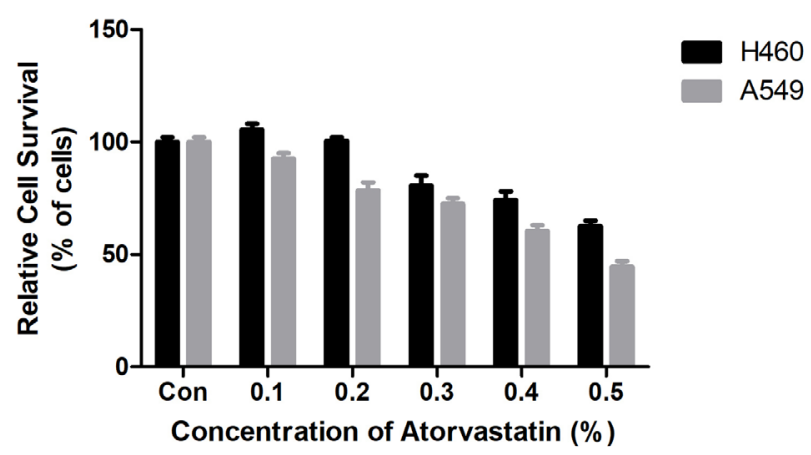

Figure S2 Dose-dependent effect of atorvastatin on cell survival of lung cancer cell lines. Data are mean \pm standard error of mean of 3 independent experiments. Student's t-test was used. ${ }^{* *} \mathrm{P}<0.01,{ }^{* *} \mathrm{P}<0.001$. Con, control; DMSO, dimethyl sulfoxide. 
Table S1 The effect of Atorvastatin on the body weight, lung weight and relative lung to body weight in benzene induced lung cancer rats

\begin{tabular}{|c|c|c|c|c|c|}
\hline S. No. & Group & Number of rats & Body weight (gm) & Lung weight (gm) & Relative lung weight \\
\hline 2 & B(a)P Control & 8 & $212.4 \pm 18.34$ & $3.05 \pm 0.09$ & 0.14 \\
\hline 3 & $\mathrm{~B}(\mathrm{a}) \mathrm{P}+\mathrm{AS}(5 \mathrm{mg} / \mathrm{kg})$ & 9 & $245.3 \pm 16.58^{*}$ & $2.76 \pm 0.06^{\star \star}$ & $0.11^{*}$ \\
\hline 4 & $B(a) P+A S(10 \mathrm{mg} / \mathrm{kg})$ & 9 & $279.4 \pm 15.96^{\star \star \star}$ & $2.12 \pm 0.04^{\star \star \star}$ & $0.08^{\star \star}$ \\
\hline
\end{tabular}

For the statically analysis via using the Bonferroni test. All the tested group compared with $\mathrm{B}(\mathrm{a}) \mathrm{P}$ group. ${ }^{*} \mathrm{P}<0.05,{ }^{\star \star} \mathrm{P}<0.01$ and ${ }^{\star \star \star} \mathrm{P}<0.001$. 